\title{
Antioxidant adaptive responses of extraembryonic tissues from cloned and non-cloned bovine conceptuses to oxidative stress during early pregnancy
}

\author{
Kaïs H Al-Gubory, Catherine Garrel ${ }^{1}$, Laurent Delatouche ${ }^{2}$, Yvan Heyman \\ and Pascale Chavatte-Palmer
}

Institut National de la Recherche Agronomique (INRA), UMR 1198 Biologie du Développement et de la Reproduction, Département de Physiologie Animale et Systèmes d'Elevage, 78352 Jouy-en-Josas cedex, France, ${ }^{1}$ Centre Hospitalier Universitaire de Grenoble, Unité de Biochimie Hormonale et Nutritionnelle, Département de Biologie Intégrée, 38043 Grenoble cedex 9, France and ${ }^{2}$ Institut National de la Recherche Agronomique (INRA), UE 1298 Unité Commune d'Expérimentation Animale, 91630 Leudeville, France

Correspondence should be addressed to K H Al-Gubory; Email: kais.algubory@jouy.inra.fr

\begin{abstract}
Placental oxidative stress has been suggested as a key factor in early pregnancy failure. Abnormal placental development limits success in pregnancies obtained by somatic cell nuclear transfer (SCNT). Malondialdehyde (MDA) content, an index of oxidative stress, and superoxide dismutase (SOD), catalase (CAT) and glutathione peroxidase (GPX) activities were determined in bovine extraembryonic tissues of SCNT or artificial insemination (AI) conceptuses. Chorionic tissues of SCNT and AI conceptuses show no difference in MDA content at day 32 of pregnancy. MDA content in chorionic tissues of SCNT and AI conceptuses decreased from day 32 to 62 of pregnancy. MDA content was lower in chorionic tissues of SCNT conceptuses than that in chorionic tissues of AI conceptuses at day 62 of pregnancy. SOD1, SOD2 and GPX activities in chorionic tissues of SCNT conceptuses were not different from those in chorionic tissues of AI conceptuses at both gestational ages. CAT activity in chorionic tissues of SCNT conceptuses was lower at day 32, and it was higher at day 62 of pregnancy than that in chorionic tissues of AI conceptuses. CAT and GPX activities increased in chorionic tissues of SCNT conceptuses with gestational age. SOD1 activity decreased while that of SOD2 and GPX increased in chorionic tissues of AI conceptuses with gestational age. At day 62 of pregnancy, MDA content and enzyme activities in cotyledonary tissues were not different between $\mathrm{AI}$ and SCNT conceptuses. Different antioxidant mechanisms may operate within the chorion of AI and SCNT conceptuses. Further experiments are required to elucidate this point.
\end{abstract}

Reproduction (2010) 140 175-181

\section{Introduction}

In domestic farm animals, such as cattle, somatic cell nuclear transfer (SCNT) is associated with pathological pregnancies (Hill et al. 1999) and important foetal losses during the first trimester of pregnancy (Hill et al. 2000) as well as in the late foetal and perinatal periods (Heyman et al. 2002). Abnormal early placental development has frequently been described in pregnancies derived from IVF and cloning procedures by SCNT in cattle (Stice et al. 1996, Hill et al. 2000, Hashizume et al. 2002, Chavatte-Palmer et al. 2006, Constant et al. 2006, Farin et al. 2006). Poor viability of cloned foetuses during days 35-60 of pregnancy is associated with rudimentary chorioallantoic development (Hill et al. 2000), fewer numbers of chorionic villi (Hashizume et al. 2002) and altered peri-implantation trophoblast differentiation (Arnold et al. 2006). Available evidence shows that aberrant expression of antioxidant enzyme proteins and associated oxidative stress in the extraembryonic tissue derived from 26-day-old SCNT conceptuses is a major factor contributing to low birth rate in pigs (Chae et al. 2006).

Oxidative stress during early placental development is associated with pregnancy-related disorders in humans, such as embryonic resorption, abortion, intra-uterine growth restriction and foetal death (Wang \& Walsh 2001, Hempstock et al. 2003, Agarwal \& Allamaneni 2004, Gupta et al. 2007). Furthermore, placental oxidative stress (Myatt \& Cui 2004, Poston \& Raijmakers 2004) may be a general underlying mechanism that links altered placental function to foetal programming (Myatt 2006). The depletion of placental antioxidant systems has been suggested as a key factor in early human pregnancy failure (Liu et al. 2006). Adequate placental antioxidant status early in pregnancy could prevent those 
disorders induced by oxidative stress that lead to impairment of placental function and development, foetal growth and pregnancy outcomes. Indeed, the effectiveness of antioxidant enzymatic defences against oxidative stress varies with the stage of placental development in humans (Sekiba \& Yoshioka 1979, Takehara et al. 1990, Qanungo et al. 1999, Jauniaux et al. 2000, Qanungo \& Mukherjea 2000) and sheep (Garrel et al. 2010). These previous data suggest that enhanced activities of key antioxidant enzymes with gestational ages may act as protective mechanism against oxidative stress during early human and sheep placental development and growth.

Reactive oxygen species (ROS) are produced in low quantities as by-products of normal aerobic metabolism. An increase in the generation of ROS and/or a decrease in cellular antioxidant capacity can induce oxidative stress (Fridovich 1999). Mammalian cells have evolved a variety of antioxidant mechanisms to control ROS-induced oxidative stress (Michiels et al. 1994). Superoxide dismutases (SODs) are metalloenzymes that catalyze the dismutation of superoxide radical $\left(\mathrm{O}_{2}^{--}\right)$into hydrogen peroxide $\left(\mathrm{H}_{2} \mathrm{O}_{2}\right)$. Thus, they constitute the first enzymatic step that plays a vital role in the control of cellular $\mathrm{O}_{2}^{--}$ production. Two intracellular isoforms of SOD have been identified in mammals. Copper-zinc-containing SOD $(\mathrm{Cu}, \mathrm{Zn}-\mathrm{SOD}$ or SOD1) is a dimeric protein, essentially located in the cytoplasm. Manganese-containing SOD (Mn-SOD or SOD2) is a homotetrameric protein, located in the mitochondria. The control of $\mathrm{H}_{2} \mathrm{O}_{2}$ production, before their subsequent transformation to highly reactive hydroxyl radical $\left(\mathrm{OH}^{*}\right)$, is the second enzymatic step that plays a vital role against ROS propagation and oxidative damage. Glutathione peroxidases (GPXs) are located within the mitochondrial matrix and the cytoplasm, and catalase (CAT) found primarily within peroxisomes, both belong to the secondary defence mechanism by catalyzing the conversion of $\mathrm{H}_{2} \mathrm{O}_{2}$ to $\mathrm{H}_{2} \mathrm{O}$. The major enzymes, SOD1, SOD2, CAT and GPX, are therefore specifically compartmentalized within the cell, and represent co-coordinately operating network of defences against oxidative stress (Fig. 1).

While the aerobic post-implantation period constitutes a critical stage of pregnancy due to high susceptibility of the developing conceptuses to oxidative stress, antioxidant defences can be altered during early placental development. Thus, the characterisation of antioxidant adaptive responses could improve the understanding of placental development, and may help in the design of a strategy for prevention and treatment of placental insufficiency, particularly in SCNT pregnancies. More than $80 \%$ of foetal deaths in the SCNT pregnancies occurred between days 30 and 60 (Hill et al. 2000). We aimed therefore to provide insights into the pro-oxidative and anti-oxidative status of bovine extraembryonic tissues derived from SCNT and artificial insemination (AI) conceptuses sampled at days 32 and

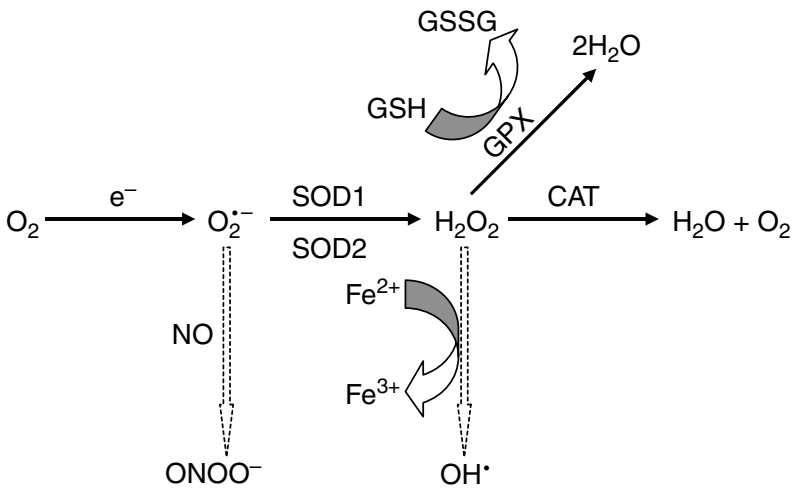

Figure 1 Schematic representation of the pathways producing reactive oxygen species (ROS) and key cellular antioxidant enzymatic systems controlling ROS production. Molecular oxygen $\left(\mathrm{O}_{2}\right)$, superoxide radical $\left(\mathrm{O}_{2}^{--}\right)$, hydrogen peroxide $\left(\mathrm{H}_{2} \mathrm{O}_{2}\right)$, nitric oxide $(\mathrm{NO})$, peroxynitrite $\left(\mathrm{ONOO}^{-}\right)$, hydroxyl radical $\left(\mathrm{OH}^{*}\right)$, copper/ zinc-superoxide dismutase (SOD1), manganese-SOD (SOD2), catalase (CAT), glutathione peroxidase $(\mathrm{GPX})$, reduced glutathione $(\mathrm{GSH})$ and oxidized glutathione (GSSG).

62 of pregnancy. In this study, we determine the content of malondialdehyde (MDA), as an index of ROS-induced oxidative stress and lipid peroxidation, along with the activities of the key antioxidant enzymes, SOD1, SOD2, CAT and GPX, in chorionic and cotyledonary tissues derived from SCNT and Al conceptuses.

\section{Results \\ MDA content in chorionic tissues at days 32 and 62 of pregnancy}

The content of MDA in chorionic tissues obtained at days 32 and 62 of pregnancy from Al and SCNT conceptuses is shown in Fig. 2. MDA content in chorionic tissues of SCNT conceptuses was not different from that in chorionic tissues of $\mathrm{Al}$ conceptuses at day 32. MDA content in chorionic tissues of $\mathrm{Al}$ conceptuses tended to be lower $(P=0.056)$ at day 62 of pregnancy than that at day 32 of pregnancy (Fig. 2). MDA content in chorionic tissues of SCNT conceptuses significantly decreased $(P<0.01)$ from day 32 to 62 of pregnancy. Chorionic tissues of SCNT conceptuses demonstrated significantly lower $(P<0.01)$ content of MDA at day 62 as compared to that in chorionic tissues of $\mathrm{Al}$ conceptuses.

\section{SOD1, SOD2, CAT and GPX activities in chorionic tissues at days 32 and 62 of pregnancy}

The activities of SOD1, SOD2, CAT and GPX in chorionic tissues obtained at days 32 and 62 of pregnancy from $\mathrm{Al}$ and SCNT conceptuses are shown in Fig. 3a-d. SOD1, SOD2 and GPX activities in chorionic tissues were not different between $\mathrm{Al}$ and SCNT conceptuses, neither at day 32 nor at day 62 of pregnancy (Fig. 3a, b and d). CAT activity in chorionic tissues of SCNT conceptuses was significantly lower 


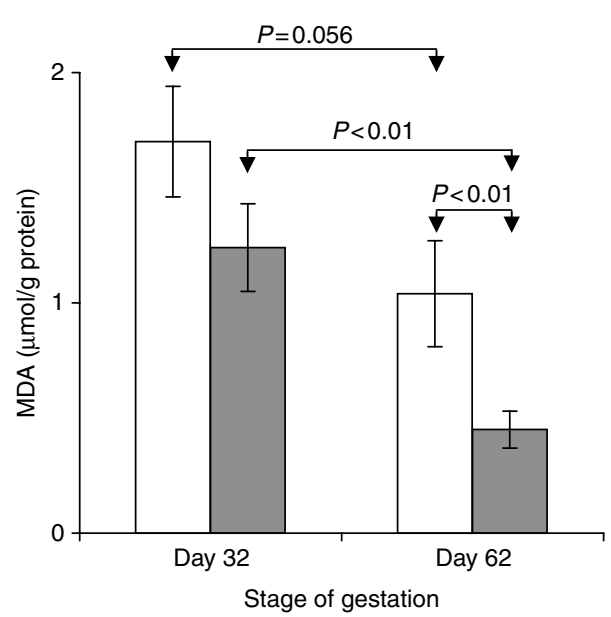

Figure 2 Malondialdehyde (MDA) content in chorionic tissues derived from Al (open bars) and SCNT (solid bars) conceptuses obtained at day 32 (four Al and four SCNT pregnant animals) and at day 62 (seven $\mathrm{Al}$ and seven SCNT pregnant animals) of pregnancy. Values are means \pm s.E.M. for the number of animals used.

$(P<0.05)$ at day 32 of pregnancy, and it was significantly higher $(P<0.05)$ at day 62 of pregnancy as compared with that in chorionic tissues of Al conceptuses (Fig. 3c). SOD1 activity in chorionic tissues of Al conceptuses significantly decreased $(P<0.05)$ from day 32 to 62 of pregnancy (Fig. 3a). SOD1 activity in chorionic tissue of SCNT conceptuses was not different between days 32 and 62 of pregnancy (Fig. 3a). SOD2 activity in Al chorionic tissues significantly increased $(P<0.01)$ from day 32 to 62 of pregnancy (Fig. 3b). SOD2 activity in chorionic tissue of SCNT conceptuses was not different between days 32 and 62 of pregnancy (Fig. 3b). CAT activity in chorionic tissue of $\mathrm{Al}$ conceptuses was not different between days 32 and 62 of pregnancy (Fig. 3c). CAT activity in chorionic tissues of SCNT conceptuses significantly increased $(P<0.01)$ from day 32 to 62 of pregnancy (Fig. 3C). GPX activity significantly increased in chorionic tissues of $\mathrm{Al}(P<0.01)$ and SCNT $(P<0.05)$ conceptuses with gestational ages (Fig. 3d).

\section{MDA content and SOD1, SOD2, CAT and GPX activities in chorionic and cotyledonary tissues at day 62 of pregnancy}

Cotyledonary tissues of $\mathrm{Al}$ and SCNT conceptuses had high activities of SOD1 $(P<0.01)$, CAT $(P<0.001$ and $P<0.05$ respectively for $\mathrm{Al}$ and SCNT conceptuses) and GPX $(P<0.001$ and $P<0.05$ respectively for $\mathrm{Al}$ and SCNT conceptuses), and low activity of SOD2 $(P<0.01$ and $P<0.05$ respectively for $\mathrm{Al}$ and SCNT conceptuses) as compared with the activities of these enzymes in chorionic tissues (Fig. 4a-d). It is interesting to note that neither MDA content (result not shown) nor SOD1, SOD2, CAT and GPX activities (Fig. 4a-d) in the cotyledonary tissues were different between $\mathrm{Al}$ and SCNT conceptuses.

\section{Discussion}

To our knowledge, this is the first report of changes in antioxidant enzymatic pathways in extraembryonic tissues derived from cloned and non-cloned conceptuses at early stages of placental development and growth. In the present study, the extent of lipid peroxidation and the activities of the key antioxidant enzymes, namely SOD1, SOD2, CAT and GPX, were determined in chorionic and cotyledonary tissues of viable bovine conceptuses obtained by SCNT biotechnology or conventional Al. Lipid peroxidation is one of the most important expressions of oxidative stress induced by ROS. MDA, an end product of lipid peroxidation processes (Mukai \& Goldstein 1976), is the most frequently used biomarkers providing an indication of
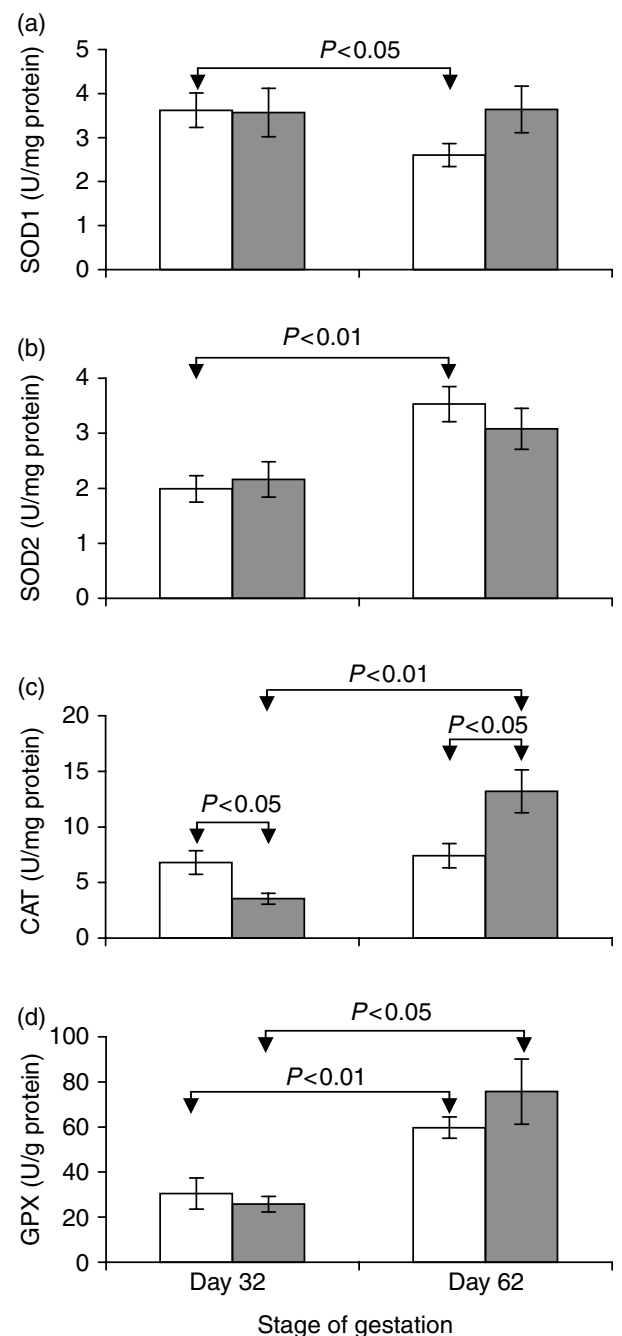

Figure 3 Changes in the enzymatic activities of (a) SOD1, (b) SOD2, (c) CAT and (d) GPX in chorionic tissues derived from Al (open bars) and SCNT (solid bars) conceptuses obtained at day 32 (four AI and four SCNT pregnant animals) and at day 62 (seven Al and seven SCNT pregnant animals) of pregnancy. Values are means \pm S.E.M. for the number of animals used. 

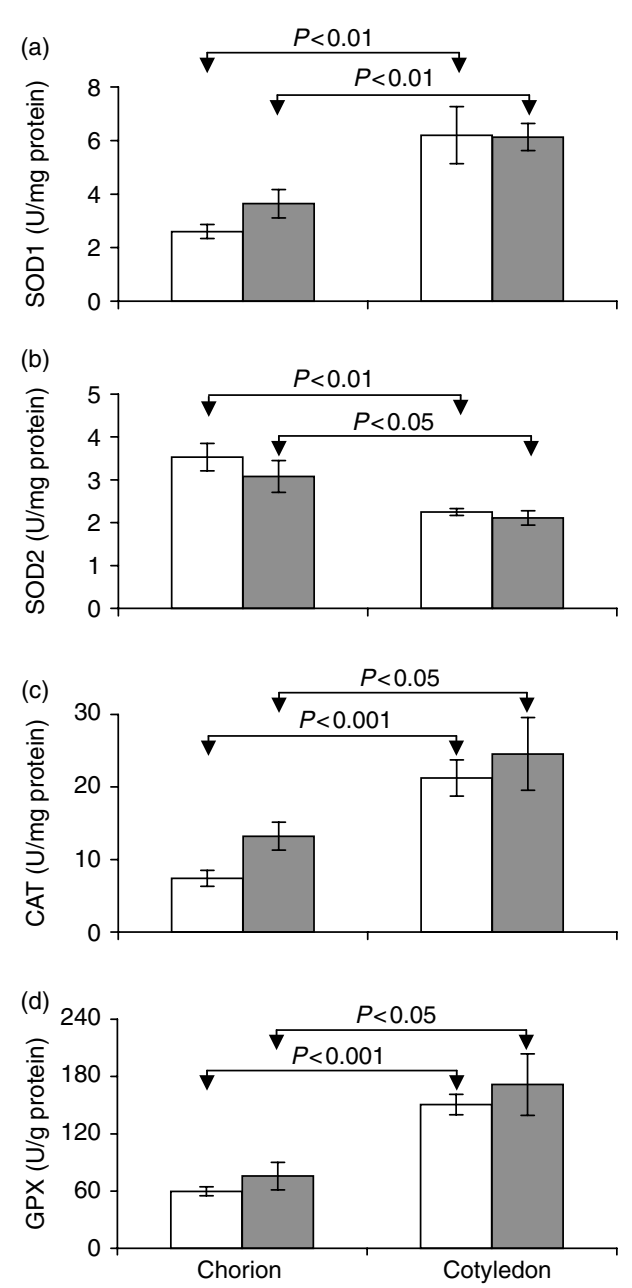

Figure 4 Enzymatic activities of (a) SOD1, (b) SOD2, (c) CAT and (d) GPX in chorionic and cotyledonary tissues derived from AI (open bars) and SCNT (solid bars) conceptuses obtained at day 62 of pregnancy (seven AI and seven SCNT pregnant animals). Values are means \pm S.E.M. for the number of animals used.

the extent of ROS-induced oxidative stress. MDA is found to be produced by the human placenta during normal or complicated pregnancy (Walsh \& Wang 1993, Poranen et al. 1996). Overall, the extent of lipid peroxidation in chorionic tissues derived from SCNT or Al conceptuses decreased as gestation proceeded (present study). Importantly, the extent of lipid peroxidation was lower in chorionic tissues derived from SCNT conceptuses than that in chorionic tissues derived from Al conceptuses at day 62 of pregnancy. This difference could be explained, at least in part, by developmental changes in the antioxidative status of chorionic tissues derived from cloned and non-cloned conceptuses with gestational age.

Chorionic tissues of $\mathrm{Al}$ conceptuses respond to oxidative stress and related lipid peroxidation MDA product early in pregnancy by increasing SOD2 and GPX activities as pregnancy progresses. This is likely to be an important cellular adaptive antioxidant mechanism because mitochondria are the major sites of endogenous ROS production (Wallace 2005). The mitochondria are therefore the prime target for ROSinduced oxidative damage. Under physiologically relevant conditions of bovine placental development between days 32 and 62 of pregnancy (present study), it may be assumed that increased activity of SOD2 and GPX in chorionic tissues of Al conceptuses would, in theory, counteract the production of ROS and the propagation of highly reactive radicals in the mitochondria and cytoplasm. The adaptive protective mechanisms that operate in chorionic tissues of SCNT conceptuses as gestation proceeds are different from those observed in chorionic tissues of $\mathrm{Al}$ conceptuses. The decrease in chorionic MDA content from day 32 to 62 of pregnancy is accompanied by an increase in CAT and GPX activities. Oxidative stress and the associated increase in the activity of $\mathrm{H}_{2} \mathrm{O}_{2}$ detoxification enzymes, CAT and GPX, have also been reported in human placental tissues of early pregnancy failure, suggesting that such an antioxidative mechanism might be developed and operate against possible oxidative damage in patients with a susceptibility for miscarriage (Biri et al. 2006). The marked increase in the activities of CAT and GPX and a decrease in MDA content from day 32 to 62 of pregnancy in bovine chorionic tissues derived from SCNT conceptuses (present study) are probably an important protective mechanism against the oxidative stress and lipid peroxidation associated with early placental development. Overall, these different operating antioxidative mechanisms within the chorion of non-cloned and cloned conceptuses obtained by Al and SCNT respectively could be a part of developmental adaptation to control oxidative stress and lipid peroxidation early in pregnancy.

Unlike $\mathrm{O}_{2}^{--}, \mathrm{H}_{2} \mathrm{O}_{2}$ is more stable, and can diffuse out of the mitochondria into the cytoplasm and the nucleus where it can lead to cell damage (Wallace 2005). In the presence of transition metals, usually iron, $\mathrm{H}_{2} \mathrm{O}_{2}$ and $\mathrm{O}_{2}^{--}$can interact in a Haber-Weiss reaction (Kehrer 2000) to generate highly toxic $\mathrm{OH}^{*}$, which is thought to be directly responsible of lipid peroxidation and oxidative damage (Halliwell 1978, Halliwell \& Gutteridge 1989). As an unstable molecule, nitric oxide (NO) may also react with $\mathrm{O}_{2}^{--}$in a reaction controlled by the rate of diffusion of both radicals to form peroxynitrite $\left(\mathrm{ONOO}^{-}\right)$, which is a powerful oxidant and a potent inducer of lipid peroxidation (Radi et al. 1991). In addition, $\mathrm{ONOO}^{-}$can react through several different mechanisms, including the formation of an intermediate through a reaction with ${ }^{\circ} \mathrm{OH}$ (Koppenol et al. 1992). Therefore, tightly controlled $\mathrm{H}_{2} \mathrm{O}_{2}$ production by CAT protects cells against lipid peroxidation by limiting the generation and propagation of highly reactive ROS. Our observation of the depression of CAT activity in chorionic tissues derived from 32-day-old bovine SCNT conceptuses as compared with that in chorionic 
tissues derived from Al conceptuses is in agreement with previous findings showing decreased CAT protein expression in the porcine extraembryonic tissue derived from 26-day-old SCNT conceptuses (Chae et al. 2006). Taken together, these previous data in pigs and our present findings in cattle suggest that aberrant expression of CAT protein and the depression of CAT enzymatic activity in chorionic tissues derived early in pregnancy from cloned conceptuses are therefore likely to decrease placental defences against deleterious $\mathrm{H}_{2} \mathrm{O}_{2}$ reactions, and could contribute to the increased lipid peroxidation during early placental development. It is important to note that the activity of CAT was increased from day 32 to 62 of pregnancy in chorionic tissues derived from SCNT conceptuses (present study). This specific adaptive response operates only in cloned conceptuses early in pregnancy and are likely to reinforce the cellular antioxidant defence systems, thereby enhancing cell tolerance against the forthcoming lipid peroxidation during placental development.

To prevent the production and propagation of highly reactive and toxic ROS, $\mathrm{H}_{2} \mathrm{O}_{2}$ generated after a SOD catalyzed reaction is quickly converted into $\mathrm{H}_{2} \mathrm{O}$ by GPX, which has selenocysteine within its active site, and therefore, it is a selenium dependent antioxidant activity. The retention of the placenta in selenium-deficient cattle suggests a role for selenium-GPX in pregnancy outcomes and foetal delivery (Eger et al. 1985). The high efficiency of GPX in controlling and limiting $\mathrm{H}_{2} \mathrm{O}_{2}$ production and the propagation of highly reactive $\mathrm{ROS}$ may be attributable to the fact that it is located in both the cytoplasm and the mitochondrial matrix, and that it can utilize both $\mathrm{H}_{2} \mathrm{O}_{2}$ and lipid peroxides as substrates. The increased GPX activity in chorionic tissues derived from Al and SCNT conceptuses with early gestational ages (present study), also reported during early placental development in humans (Jauniaux et al. 2000), and sheep (Garrel et al. 2010), is probably an important adaptive mechanism protecting the early placenta against ROS-mediated lipid peroxidation and cell damage. Possibly chorionic cells induce enhancement of GPX to counteract the generation of $\mathrm{H}_{2} \mathrm{O}_{2}$ and the subsequent propagation of highly toxic ROS known to induce lipid peroxidation.

The present study for the first time provides insight into the enzymatic antioxidant status of the extraembryonic tissues derived from cloned and non-cloned bovine conceptuses. We have demonstrated that the activities of the key antioxidant enzymes show major changes in chorionic tissues of SCNT and Al conceptuses during early placental development. Enhanced activities of $\mathrm{H}_{2} \mathrm{O}_{2}$ detoxification enzymes, namely CAT and GPX, with gestational age observed in the chorion derived from SCNT conceptuses may represent a protective or adaptive mechanism to prevent damage from oxidative insult early in pregnancy.

\section{Materials and Methods}

\section{Bovine somatic cell nuclear transfer}

Methods of somatic clone embryo production were as previously described (Vignon et al. 1998). Briefly, bovine ovaries were collected from the abattoir and transported in sterile PBS. Cumulus-oocyte complexes (COCs) were aspirated from follicles 2 to $7 \mathrm{~mm}$ in diameter, washed and selected morphologically for in vitro maturation. Batches of 30-40 COCs were matured in TCM-199 containing 10\% (v/v) FCS (Life Technologies, Paisleys, Scotland, UK), $10 \mu \mathrm{g} \mathrm{FH} / \mathrm{ml}$ and $1 \mu \mathrm{g} \mathrm{LH} / \mathrm{ml}$ for $22 \mathrm{~h}$ at $39^{\circ} \mathrm{C}$ in a humidified atmosphere of $5 \%$ $\mathrm{CO}_{2}$ in air. Skin cells from three different adult females of Holstein bred were cultured over several passages before being used for nuclear transfer (NT). Cells were trypsinated, pelleted at $1200 \mathrm{~g}$ for $5 \mathrm{~min}$ and resuspended in fresh medium prior to NT. Each isolated cell was inserted under the zona pellucida of the recipient cytoplast and fused by electrostimulation. Reconstituted embryos were co-cultured in microdrops of $50 \mu \mathrm{l} \mathrm{B2}$ medium (CCD, Paris, France) with $2.5 \%$ FCS and vero cells. After 7 days of in vitro culture at $39{ }^{\circ} \mathrm{C}$ and under $5 \%$ $\mathrm{CO}_{2}$, expanding or hatching blastocysts (grade 1) were removed from the culture drops and were transferred into the uterus of synchronized recipient Holstein heifers.

\section{Embryo transfer}

Recipient heifers, 15-18 months of age, were treated for oestrus synchronisation with progestagen implants for 9 days (Crestar, Intervet, Angers, France). Two days before removal of implant, each heifer was treated with an analogue of prostaglandin $F_{2 \alpha}$ (0.5 mg Estrumate/2 $\mathrm{ml}$ per day, Schering-Plough Vétérinaire, Levallois-Perret, France). One week after induced oestrus, heifers with a palpable corpus luteum $(\mathrm{CL})$ were used. SNCT pregnancies were obtained after non-surgical transfer of a single NT blastocyst into the uterine horn ipsilateral to the $C L$ of each recipient animal using the miniaturized embryo transfer syringe and sanitary sheath (IMV, L'Aigle, France) under epidural anaesthesia. Control pregnancies were obtained after $\mathrm{Al}$ of Holstein heifers using frozen semen from a single Holstein bull. Control Al pregnant heifers were bred and managed in the same facilities as SNCT pregnant heifers (INRA, Unité Commune d'Expérimentation Animale, Leudeville, France). Pregnancy was made by transrectal ultrasonography at days 29-30 and then repeated at days 45 and 60 of gestation.

\section{Tissue collection}

Pregnant animals bearing SCNT or AI viable conceptuses were randomly allocated for slaughter at days 32 and 62 of gestation. The animals were humanely put down at the experimental slaughterhouse of INRA in accordance with protocols approved by the institutional ethical committee. The reproductive tracts were collected and immediately transported to the laboratory adjacent to the slaughterhouse for tissue dissection. Chorionic tissues from cloned and non-cloned conceptuses were sampled at day 32 (four SCNT and four AI pregnant animals) and at day 62 (seven SCNT and seven Al pregnant animals) of pregnancy, and cotyledonary tissues were collected at day 62 of pregnancy (seven SCNT and 
seven Al pregnant animals). Immediately after dissection, chorionic and cotyledonary tissues were snap-frozen in liquid nitrogen, and then stored at $-80{ }^{\circ} \mathrm{C}$ until processed for MDA content and SOD1, SOD2, CAT and GPX enzymatic activities.

\section{Antioxidant enzyme activity assays}

Chorionic and cotyledonary tissues were homogenized separately in cold phosphate buffer $(50 \mathrm{mM}, \mathrm{pH} 7.4)$, and then, the homogenates were centrifuged at $15000 \mathrm{~g}$ for $30 \mathrm{~min}$ at $4{ }^{\circ} \mathrm{C}$. The resulting supernatant was used for determination of protein concentration, MDA content and measurement of enzymatic activities. Protein concentrations were determined by Lowry's method (Lowry et al. 1951). Enzyme activities of SOD1, SOD2, CAT and GPX in the supernatant were determined as described previously in detail (Al-Gubory et al. 2005, Garrel et al. 2007). Total SOD activity was measured using the pyrogallol assay based on the competition between pyrogallol oxidation by superoxide radicals and superoxide dismutation by SOD (Marklund \& Marklund 1974). SOD2 is encoded in the nuclear chromatin, synthesized as a precursor in the cytoplasm, and imported posttranslationally into the mitochondrial matrix in its mature form (Wispe et al. 1989). The freeze-thaw approach results in mitochondrial release of large amounts of SOD2 into the cytosol (Jin et al. 2005). Enzymatic activity of SOD2 was determined by assaying for SOD activity in the presence of sodium cyanide, which selectively inhibits SOD1 but not SOD2 (Jin et al. 2005). SOD1 activity was calculated by subtracting SOD2 activity from total SOD activity. The rate of auto-oxidation is taken from the increase in the absorbance at $420 \mathrm{~nm}$. One unit of SOD activity is defined as the amount of the enzyme required to inhibit the rate of pyrogallol auto-oxidation by $50 \%$. CAT activity was determined as described previously (Nzengue et al. 2008). Activity was assayed by determining the rate of decomposition of $\mathrm{H}_{2} \mathrm{O}_{2}$ by CAT in $10 \mathrm{mM}$ of potassium phosphate buffer $(\mathrm{pH} 7)$. The reaction rate was related to the amount of CAT present in the mixture. The rate of $\mathrm{H}_{2} \mathrm{O}_{2}$ decomposition by CAT was followed at $240 \mathrm{~nm}$. One unit was defined as the decomposition of $1 \mathrm{mmol} \mathrm{H}_{2} \mathrm{O}_{2}$ per min per $\mathrm{mg}$ protein. GPX activity was measured using the glutathione reductase-NADPH method. Activity was determined by a coupled assay system, in which oxidation of glutathione was coupled to NADPH oxidation catalyzed by glutathione reductase. The rate of glutathione oxidized by tertiary butyl hydroperoxide was evaluated by the decrease of NADPH in the presence of EDTA, excess reduced glutathione and glutathione reductase. The rate of decrease in concentration of NADPH was recorded at $340 \mathrm{~nm}$. GPX activity was expressed in terms of $\mathrm{nM}$ of $\mathrm{NADPH}$ oxidized per min per mg protein.

\section{MDA measurement}

The most widely used method for the determination of MDA in biological materials is based on its reaction with thiobarbituric acid (TBA). Reversed-phase HPLC technique in which the MDA-TBA adducts are separated from interfering substances (Londero \& Lo Greco 1996) was used for determining MDA in chorionic and cotyledonary tissue homogenates. The breakdown product of 1,1,3,3-tetraethoxypropane (TEP) was used as standard. TEP undergoes hydrolysis to liberate stoichiometric amounts of MDA. Stock standard solution $(480 \mu \mathrm{l}$ of TEP in $100 \mathrm{ml}$ ethanol) was prepared, and this primary solution was diluted to the concentrations of 0,1 , $2,3,4,5$ and $6 \mu \mathrm{M}$. Tissue extract aliquots or standards $(100 \mu \mathrm{l})$ were mixed with $750 \mu \mathrm{l}$ of $0.8 \%$ TBA. The tubes were placed in a water bath at $95^{\circ} \mathrm{C}$ for $1 \mathrm{~h}$, and then, they were cooled. Samples were neutralized with methanol-NaOH mixture $(\mathrm{pH}$ 6). After centrifugation, $50 \mu \mathrm{l}$ of protein-free supernatant were chromatographed in the HPLC system. The column used for the separation was Adsorbosphere C18 $(5-\mu \mathrm{m}$ particle diameter, $250 \times 4.6 \mathrm{~mm}$ ID). The MDA-TBA adduct is eluted from the column with potassium dihydrogen phosphate buffer $(10 \mathrm{mM}$, $\mathrm{pH}$ 6.0)-acetonitrile (17\%). The quantification of MDA derivative was established by comparing the absorption to the standard curve of MDA equivalents generated by acidcatalyzed hydrolysis of TEP as $\mu$ mols per gram tissue protein.

\section{Statistical analysis}

The MDA content and the enzymatic activities were analyzed by one-way ANOVA and the Newman-Keuls multiple comparison test (PRISM Graph Pad version 2; Graph Pad Software, San Diego, CA, USA). The acceptable level of significance was set at $P<0.05$. Data are presented as the mean \pm s.E.M.

\section{Declaration of interest}

The authors declare that there is no conflict of interest that could be perceived as prejudicing the impartiality of the research reported.

\section{Funding}

This project was supported by the INRA, Département de Physiologie Animale et Systèmes d'Elevage (PHASE).

\section{Acknowledgements}

The authors would like to thank Krawiec Angele, Catherine Mangournet, Sandra Grange, Christine Tozzoli, Cécile Mounioz, Daniel LeBourhis and Philippe Bolifraud for their excellent technical assistance. The authors also thank the staff of the UCEA (INRA, Unité Commune d'Expérimentation Animale, Domaine de Bressonvilliers, Leudeville, France) for outstanding cattle management.

\section{References}

Agarwal A \& Allamaneni SSR 2004 Role of free radicals in female reproductive diseases and assisted reproduction. Reproductive Biomedicine Online 9 338-347.

Al-Gubory KH, Ceballos-Picot I, Nicole A, Bolifraud P, Germain G, Michaud M, Mayeur C \& Blachier F 2005 Changes in activities of superoxide dismutase, nitric oxide synthase, glutathione-dependent enzymes and the incidence of apoptosis in sheep corpus luteum during the estrous cycle. Biochimica et Biophysica Acta 1725 348-357.

Arnold DR, Bordignon V, Lefebvre R, Murphy BD \& Smith LC 2006 Somatic cell nuclear transfer alters peri-implantation trophoblast differentiation in bovine embryos. Reproduction 132 279-290. 
Biri A, Kavutcu M, Bozkurt N, Devrim E, Nurlu N \& Durak I 2006 Investigation of free radical scavenging enzyme activities and lipid peroxidation in human placental tissues with miscarriage. Journal of the Society for Gynecologic Investigation 13 384-388.

Chae JI, Cho SK, Seo JW, Yoon TS, Lee KS, Kim JH, Lee KK, Han YM \& Yu K 2006 Proteomic analysis of the extraembryonic tissue from cloned porcine embryos. Molecular and Cellular Proteomics 5 1559-1566.

Chavatte-Palmer P, de Sousa N, Laigre P, Camous S, Ponter AA, Beckers JF \& Heyman Y 2006 Ultrasound fetal measurements and pregnancy associated glycoprotein secretion in early pregnancy in cattle recipients carrying somatic clones. Threiogenology 66 829-840.

Constant F, Guillomot M, Heyman Y, Vignon X, Laigre P, Servely JL, Renard JP \& Chavatte-Palmer P 2006 Large offspring or large placenta syndrome? Morphometric analysis of late gestation bovine placentomes from somatic nuclear transfer pregnancies complicated by hydrallantois Biology of Reproduction 75 122-130.

Eger S, Drori D, Kadoori I, Miller N \& Schindler H 1985 Effects of selenium and vitamin E on incidence of retained placenta. Journal of Dairy Science 68 2119-2122.

Farin PW, Piedrahita JA \& Farin CE 2006 Errors in development of fetuses and placentas from in vitro-produced bovine embryos. Theriogenology 65 178-191.

Fridovich I 1999 Fundamental aspects of reactive oxygen species, or what's the matter with oxygen? Annals of the New York Academy of Sciences $89313-18$.

Garrel C, Ceballos-Picot I, Germain G \& Al-Gubory KH 2007 Oxidative stress-inducible antioxidant adaptive response during prostaglandin $\mathrm{F}_{2 \alpha^{-}}$ induced luteal cell death in vivo. Free Radical Research 41 251-259.

Garrel C, Fowler PA \& Al-Gubory KH 2010 Developmental changes in antioxidant enzymatic defences against oxidative stress in sheep placentomes. Journal of Endocrinology 205 107-116.

Gupta S, Agarwal A, Banerjee J \& Alvarez JG 2007 The role of oxidative stress in spontaneous abortion and recurrent pregnancy loss: a systematic review. Obstetrical and Gynecological Survey 62 335-347.

Halliwell B 1978 Superoxide-dependent formation of hydroxyl radicals in the presence of iron chelates: is it a mechanism for hydroxyl radical production in biochemical systems? FEBS Letters 92 321-326.

Halliwell B \& Gutteridge JMC 1989 Protection against oxidants in biological systems: the superoxide theory of oxygen toxicity. In Free Radical in Biology and Medicine, pp 86-123. Eds B Halliwell \& JMC Gutteridge. Oxford: Clarendon Press.

Hashizume K, Ishiwata H, Kizaki K, Yamada O, Takahashi T, Imai K, Patel OV, Akagi S, Shimizu M, Takahashi S et al. 2002 Implantation and placental development in somatic cell clone recipient cows. Cloning and Stem Cells 4 197-209.

Hempstock J, Jauniaux E, Greenwold N \& Burton GJ 2003 The contribution of placental oxidative stress to early pregnancy failure. Human Pathology 34 1265-1275.

Heyman Y, Chavatte-Palmer P, LeBourhis D, Camous S, Vignon X \& Renard JP 2002 Frequency and occurrence of late gestation losses from cattle cloned embryos. Biology of Reproduction 66 6-13.

Hill JR, Roussel AJ, Cibelli JB, Edwards JF, Hooper RN, Miller MW, Thompson JA, Looney CR, Westhusin ME, Robl JM et al. 1999 Clinical and pathologic features of cloned transgenic calves and fetuses (13 case studies). Theriogenology 51 1451-1465.

Hill JR, Burghardt RC, Jones K, Long CR, Looney CR, Shin T, Spencer TE, Thompson JA, Winger QA \& Westhusin ME 2000 Evidence for placental abnormality as the major cause of mortality in first-trimester somatic cell cloned bovine fetuses. Biology of Reproduction 63 1787-1794.

Jauniaux E, Watson AL, Hempstock J, Bao YP, Skepper JN \& Burton GJ 2000 Onset of maternal arterial blood flow and placental oxidative stress. A possible factor in human early pregnancy failure. American Journal of Pathology 157 2111-2122.

Jin ZQ, Zhou HZ, Cecchini G, Gray MO \& Karliner JS 2005 MnSOD in mouse heart: acute responses to ischemic preconditioning and ischemiareperfusion injury. American Journal of Physiology. Heart and Circulatory Physiology $288 \mathrm{H} 2986-\mathrm{H} 2994$.

Kehrer JP 2000 The Haber-Weiss reaction and mechanisms of toxicity. Toxicology 149 43-50.

Koppenol WH, Moreno JJ, Pryor WA, Ischiropoulos H \& Beckman JS 1992 Peroxynitrite, a cloaked oxidant formed by nitric oxide and superoxide. Chemical Research in Toxicology 5 834-842.
Liu AX, Jin F, Zhang WW, Zhou TH, Zhou CY, Yao WM, Qian YL \& Huang HF 2006 Proteomic analysis on the alteration of protein expression in the placental villous tissue of early pregnancy loss. Biology of Reproduction 75 414-420.

Londero D \& Lo Greco P 1996 Automated high-performance liquid chromatographic separation with spectrofluorometric detection of a malondialdehyde-thiobarbituric acid adduct in plasma. Journal of Chromatography. A 729 207-210.

Lowry OH, Rosebrough NJ, Farr AL \& Randall RF 1951 Protein measurement with folin phenol reagent. Journal of Biological Chemistry $193265-275$.

Marklund S \& Marklund G 1974 Involvement of the superoxide anion radical in the autoxidation of pyrogallol and a convenient assay for superoxide dismutase. European Journal of Biochemistry 47 469-474.

Michiels C, Raes M, Toussaint O \& Remacle J 1994 Importance of Se-glutathione peroxidase, catalase, and $\mathrm{Cu} / \mathrm{Zn}$-SOD for cell survival against oxidative stress. Free Radical Biology \& Medicine 17 235-248.

Mukai FH \& Goldstein BD 1976 Mutagenicity of malondialdehyde, a decomposition product of peroxidised polyunsaturated fatty acids. Science 191 868-869.

Myatt L 2006 Placental adaptive responses and fetal programming. Journal of Physiology 572 25-30.

Myatt L \& Cui X 2004 Oxidative stress in the placenta. Histochemistry and Cell Biology 122 369-382.

Nzengue Y, Steiman R, Garrel C, Lefèbvre E \& Guiraud P 2008 Oxidative stress and DNA damage induced by cadmium in the human keratinocyte HaCaT cell line: role of glutathione in the resistance to cadmium. Toxicology 243 193-206.

Poranen AK, Ekblad U, Uotila P \& Ahotupa M 1996 Lipid peroxidation and antioxidants in normal and pre-eclamptic pregnancies. Placenta 17 401-405.

Poston L \& Raijmakers MTM 2004 Trophoblast oxidative stress, antioxidants and pregnancy outcome - a review. Placenta 25 S72-S78.

Qanungo S \& Mukherjea M 2000 Ontogenic profile of some antioxidants and lipid peroxidation in human placental and fetal tissues. Molecular and Cellular Biochemistry 215 11-19.

Qanungo S, Sen A \& Mukherjea M 1999 Antioxidant status and lipid peroxidation in human feto-placental unit. Clinica Chimica Acta $\mathbf{2 8 5}$ $1-12$.

Radi R, Beckman JS, Bush KM \& Freeman BA 1991 Peroxynitrite induced membrane lipid peroxidation: the cytotoxic potential of superoxide and nitric oxide. Archives of Biochemistry and Biophysics 288 481-487.

Sekiba K \& Yoshioka T 1979 Changes of lipid peroxidation and superoxide dismutase activity in the human placenta. American Journal of Obstetrics and Gynaecology 135 368-371.

Stice SL, Strelchenko NS, Keefer CL \& Matthews L 1996 Pluripotent bovine embryonic cell lines direct embryonic development following nuclear transfer. Biology of Reproduction 54 100-110.

Takehara Y, Yoshioka T \& Sasaki J 1990 Changes in the levels of lipoperoxide and antioxidant factors in human placenta during gestation. Acta Medica Okayama 44 103-111.

Vignon X, Chesné P, Lebourhis D, Fléchon JE, Heyman Y \& Renard JP 1998 Developmental potential of bovine embryos reconstructed with enucleated matured oocytes fused with cultured somatic cells. Comptes Rendus de l'Académie des Sciences 321 735-745.

Wallace DC 2005 A mitochondrial paradigm of metabolic and degenerative diseases, aging, and cancer: a dawn for evolutionary medicine. Annual Review of Genetics 39 359-407.

Walsh SW \& Wang Y 1993 Secretion of lipid peroxides by the human placenta. American Journal of Obstetrics and Gynaecology 169 1462-1466.

Wang Y \& Walsh SW 2001 Increased superoxide generation is associated with decreased superoxide dismutase activity and mRNA expression in placental trophoblast cells in pre-eclampsia. Placenta 22 206-212.

Wispe JR, Clark JC, Burhans MS, Kropp KE, Korfhagen TR \& Whitsett JA 1989 Synthesis and processing of the precursor for human manganosuperoxide dismutase. Biochimica et Biophysica Acta 994 30-36.

Received 6 April 2010

First decision 20 April 2010

Accepted 30 April 2010 